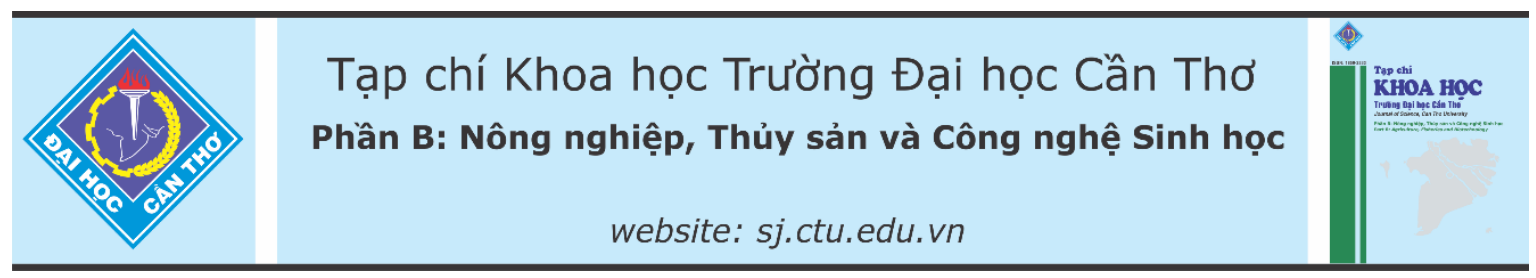

DOI:10.22144/ctu.jvn.2021.123

\title{
SỬ DỤNG MÀNG CHITOSAN TRONG BẢO QUẢN CHẢ CÁ LÓC CHIÊN Ở NHIẸTT Độ THẤP
}

\author{
Võ Hoàng Ngân ${ }^{1}$, Nguyễn Văn Mười ${ }^{2}$ và Trần Thanh Trúc ${ }^{3 *}$ \\ ${ }^{1}$ Sở Khoa họ và Công nghệ tỉnh Vĩnh Long \\ ${ }^{2}$ Khoa Nông nghiệp, Truờng Đại học Cần Tho \\ ${ }^{3}$ Khoa Sau Đại họ, Truòng Đại hoc Cần Tho \\ *Người chịu trách nhiệm về bài viết: Trần Thanh Trúc (email:tttruc@ctu.edu.vn)
}

\section{Thông tin chung:}

Ngày nhận bài: $28 / 02 / 2021$

Ngày nhận bài sưa: 03/04/2021

Ngày duyệt đăng: 20/08/2021

\section{Title:}

The application of chitosan coating in the low-temperature storage of fried snakehead fish cake

\section{Tù khóa:}

Bảo quản, chả cá lóc chiên, chitosan, nhiệt độ, sodium tripolyphosphate

\section{Keywords:}

Chitosan, fried snakehead fish cake, low temperature, sodium tripolyphotphate, storage

\begin{abstract}
The study was conducted with the main objective of investigating the ability to store fried snakehead fish cakes at low temperatures using edible chitosan film. The contents of the study include (i) determining the appropriate concentration of chitosan used to wrap fried snakehead fish cakes, (ii) studying the ability to preserve fried snakehead fish cakes of different types of chitosan films at cold temperatures, and (iii) assessing the ability to preserve fried snakehead fish cakes of chitosan films under frozen conditions. The study results showed that a chitosan solution of $1.5 \%$ concentration is most suitable for wrapping fried snakehead fish cakes. Also, preserving with 1.5\% chitosan film combined with sodium tripolyphosphate at a concentration of $0.2 \%$, with a 2-minute dip time, can help improve the ability to inhibit the growth of microorganisms and maintain the quality of fish cake compared to using chitosan films. With the coating support, the preservation time of fried snakehead fish was 8 weeks of cold storage and 12 weeks of frozen storage, respectively with product quality not changing significantly and microbiological safety.
\end{abstract}

\section{TÓM TẮT}

Nghiên cưu được thực hiện với mục tiêu chính là khảo sát khả năng bảo quản chả cá lóc chiên ở nhiệt độ thấp sủ dụng màng chitosan ăn được. Các nội dung đã được tiến hành trong nghiên cứu bao gồm: (i) xác định nồng độ chitosan thích hợp dùng để bao màng sản phẩm chả cá lóc chiên, (ii) nghiên cứu khả năng bảo quản chả cá lóc chiên của các loại màng chitosan ở điều kiện nhiệt độ lạnh và (iii) đánh giá khả năng bảo quản chả cá lóc chiên của các loại màng chitosan ở điều kiện trũ đông. Kết quả nghiên cứu giúp xác định được, dung dịch chitosan có nồng độ 1,5\% là thich hợp nhất để bao màng chả cá lóc chiên. Bên cạnh đó, việc bảo quản bằng màng chitosan 1,5\% kết hợp sodium tripolyphosphate ở nồng độ $0,2 \%$, với thời gian nhúng 2 phút giúp cải thiện khả năng úc chế sư phát triển của vi sinh vật và duy trì chất lượng của chả so với sử dụng màng chitosan riêng lé. Vói sụ hố trợ của màng bao, thời gian bảo quản của chả cá lóc chiên tuoong ứng đạt 8 tuần bảo quản lạnh và 12 tuần trũ đông với chất luợng sản phẩm thay đổi không đáng kể và đảm bảo an toàn về vi sinh. 


\section{GIỚI THIẸU}

Nuôi trồng và chế biến thủy sản là một trong những ngành kinh tế mũi nhọn của Việt Nam nói chung và vùng Đồng bằng sông Cửu Long nói riêng. Các loài thủy sản được nuôi với sản lượng lớn ở vùng đồng bằng sông Cửu Long chủ yếu là cá tra, cá điêu hồng, tôm và gần đây là sự phát triển mạnh mẽ của nghề nuôi cá lóc (Lê Xuân Sinh \& Đỗ் Minh Chung, 2009). Tuy nhiên, sản lượng cá lóc nuôi tăng lên nhanh chóng do việc mở rộng diện tích nuôi một cách tự phát, không theo quy hoạch đã dẫn đến tình trạng khó khăn trong tiêu thụ, làm giá cả bấp bênh,... Chính vì thế, việc sử dụng thịt cá lóc trong chế biến sản phẩm chất lượng cao, đặc biệt là sản phẩm chả cá lóc chiên có chất lượng và cảm quan cao đã được nghiên cứu thành công bởi Trần Thanh Trúc và ctv. (2016) và Vo et al. (2018) góp phần ổn định đầu ra cho nguyên liệu, tạo ra sản phẩm mới mang tính cạnh tranh trên thị trường, đa dạng hóa sản phẩm đồng thời nâng cao thu nhập và cải thiện đời sống của người dân. Với giá trị dinh dưỡng cũng như độ ẩm cao, chả cá lóc sẽ nhanh chóng mất ẩm kéo theo việc giảm khối lượng, giảm giá trị dinh dưỡng và xảy ra nhiều biến đổi không mong muốn do hoạt động của vi sinh vật. Do đó, việc sử dụng các phụ gia bảo quản có nguồn gốc tự nhiên như chitosan được chiết xuất từ vỏ tôm trong duy trì chất lượng và kéo dài thời gian bảo quản chả cá lóc có ý nghĩa quan trọng. Vì vậy, việc nghiên cứu sử dụng màng chitosan trong bảo quản chả cá lóc chiên ở nhiệt độ thấp được thực hiện với mong muốn duy trì chất lượng và kéo dài thời gian bảo quản sản phẩm.

\section{PHƯƠNG PHÁP NGHIÊN CÚU}

\subsection{Phương tiện nghiên cứu}

Nguyên liệu: Cá lóc nuôi có khối lượng từ 400 đến $700 \mathrm{~g}$ (khối lượng thu hoạch phổ biến và phù hợp cho chế biến chả, Vo et al., 2018) được thu mua trực tiếp tại vùng nuôi cá lóc ở huyện Tam Bình, tỉnh Vĩnh Long. Cá sau khi thu mua được vận chuyển dạng sống (chứa trong thùng nước) về phòng thí nghiệm, thời gian vận chuyển khoảng 1 giờ. Tại phòng thí nghiệm, cá lóc sống được để ổn định trong bể nước ít nhất một giờ trước khi tiến hành các công đoạn xử lý tiếp theo (Trần Thanh Trúc và ctv., 2016).

\section{Phu gia, gia vị sủ dụng}

- STPP (Sodium tripolyphosphate, Pháp).

- Chitosan được cung cấp bởi Công ty TNHH Một thành viên Chitosan VN.
- Tiêu, tỏi, đường, bột ngọt và các thành phần phụ gia khác được mua từ các siêu thị tại thành phố Cần Thơ, theo các Tiêu chuẩn Việt Nam dùng cho chế biến thực phẩm và còn thời hạn sử dụng.

\subsection{Phương pháp bố trí thí nghiệm}

\subsubsection{Chuẩn bị nguyên liệu}

Cá lóc sau khi để ổn định được cân khối lượng trước khi làm ngất, cắt tiết và xả máu trong nước chảy tràn để đảm bảo loại bỏ máu hoàn toàn. Cá sau khi cắt tiết được chuyển sang đánh vảy, bỏ mang, nắp mang, nội tạng, đầu và được rửa trong nước muối với nồng độ $0,5 \%$. Sau đó tiến hành lột da và fillet lấy phần thịt cá. Rửa lại thịt cá bằng nước sạch, nước rửa phải được giữ ở nhiệt độ thấp 5 đến $10^{\circ} \mathrm{C}$ nhằm tránh các biến đổi sinh hóa trong nguyên liệu và sự phát triển của vi sinh vật gây ảnh hưởng đến chất lượng của sản phẩm (Trần Thanh Trúc và ctv., 2016). Cân xác định hiệu suất thu hồi, fillet cá được cắt thành nhiều khúc và cho vào túi $\mathrm{PE}(0,5 \mathrm{~kg} /$ túi $)$ để tiện lợi cho lạnh đông nguyên liệu. Tiến hành lạnh đông cá ở nhiệt độ $-18^{\circ} \mathrm{C}$ ít nhất 24 giờ trước khi sử dụng cho nghiên cứu (Vo et al., 2018). Nguyên liệu của mỗi đợt lấy mẫu đều được phân tích các chỉ tiêu hóa lý.

\subsubsection{Chuẩn bị mẫu chả cá lóc chiên}

Quy trình chế biến sản phẩm chả cá lóc sử dụng làm nguyên liệu cho các khảo sát trong nghiên cứu được thực hiện như kết quả từ nghiên cứu của Trần Thanh Trúc và ctv. (2016) và Vo et al. (2018).

Thịt cá lóc sau lạnh đông sẽ được xay thô để phá vỡ cấu trúc và phối trộn phụ gia bao gồm $1,32 \%$ muối, $6,17 \%$ nước đá, $1,5 \%$ sorbitol, $1,5 \%$ succrose, $0,2 \%$ sodium tripolyphosphate, $3 \%$ tinh bột biến tính, $0,5 \%$ bột tiêu, $0,5 \%$ bột tỏi và $0,3 \%$ bột ngọt. Sau mỗi phụ gia bồ sung tiến hành xay phối trộn 30 giây sau đó tiến hành xay mịn khối thịt cá để tạo khối paste hoàn chỉnh. Phần paste sau khi xay mịn sẽ được định hình ở dạng miếng tròn (chiều dày trung bình 14 đến $15 \mathrm{~mm}$, đường kính 68 đến 70 $\mathrm{mm}$, khối lượng mỗi mẫu khoảng $50 \mathrm{~g}$ ). Sau khi định hình, chả cá miếng được giữ trong tủ mát từ 2-6 giờ ở nhiệt độ từ 2 đển $4{ }^{\circ} \mathrm{C}$ để ổn định lại cấu trúc gel (Nguyen et al., 2019) và chờ để được hấp sơ bộ ở nhiệt độ $60 \pm 2^{\circ} \mathrm{C}$ trong thời gian 30 phút. Sau khi chiên ngập trong dầu ở nhiệt độ $180^{\circ} \mathrm{C}$ trong thời gian 3 phút, sản phẩm chả cá được để nguội ngoài không khí đến nhiệt độ phòng. Sản phẩm chả cá lóc chiên sẽ được nhúng màng chitosan với nồng độ khác nhau và làm khô trước khi tiến hành bảo quản ở các điều kiện nhiệt độ thấp. 


\subsubsection{Thí nghiệm 1: Xác định nồng độ chitosan thích hợp dùng để bao màng chả cá lóc chiên}

Thí nghiệm được tiến hành với mục tiêu xác định nồng độ chitosan thích hợp nhằm hạn chế sự phát triển của vi sinh vật trong bảo quản lạnh chả cá lóc chiên. Chả cá lóc chiên được chuẩn bị đồng nhất như ở mục 2.2.2, chả sau chiên được để nguội trước khi phủ màng chitosan theo phương pháp nhúng trực tiếp trong thời gian cố định 2 phút ở các nồng độ $0,5 \%, 1 \%, 1,5 \%, 2 \%$ của chitosan được hòa tan trong dung dịch acetic acid $1 \%$, mẫu đối chứng không phủ màng chitosan. Chả sau phủ màng được làm khô trong tủ lạnh $\left(4 \pm 2^{\circ} \mathrm{C}\right)$ và cho vào bao bì $\mathrm{PA}$, điều chỉnh độ chân không $90 \%$, sản phẩm được bảo quản trong tủ lạnh chờ phân tích chỉ tiêu vi sinh vật hiếu khí tổng số sau thời gian $0,1,3$ tuần bảo quản.

\subsubsection{Thí nghiệm 2: Nghiên cúu ảnh hwởng của việc bổ sung kết hợp sodium tripolyphosphate và chitosan đến khả năng bảo quản lạnh và lạnh đông chả cá lóc chiên}

Thí nghiệm giúp xác định được sự thay đổi chất lượng chả cá lóc chiên do tác động của màng chitosan có và không có bổ sung sodium tripolyphosphate (STPP) khi bảo quản lạnh. Chả cá sau công đoạn chiên được để nguội ở nhiệt độ phòng và tiến hành nhúng vào dung dịch chitosan có nồng độ được lựa chọn từ thí nghiệm 1 , ở mẫu còn lại, sử dụng dung dịch chitosan được kết hợp với sodium tripolyphosphate $0,2 \%$ (nồng độ STPP tối đa được thêm có thể hòa tan vào dịch màng chitosan) trong thời gian 2 phút. Chả sau nhúng màng được làm khô bằng tủ mát, sau đó cho vào bao bì $\mathrm{PA}$ hút chân không $90 \%$ và bảo quản ở 2 điều kiện nhiệt độ lạnh $\left(4 \pm 2^{\circ} \mathrm{C}\right)$ và lạnh đông $\left(-20 \pm 2^{\circ} \mathrm{C}\right)$. Các chỉ tiêu cần phân tích được thu nhận tại các công đoạn trước khi đưa vào bảo quản và sau mỗi 1-3 tuần bảo quản (phân tích đến tuần bảo quản thứ 8 đối với bảo quản lạnh và tuần thứ 12 đối với chả cá trữ đông).

\subsection{Phương pháp thu thập và xử lý số liệu}

Các thí nghiệm trong nghiên cứu được bố trí ngẫu nhiên, lặp lại 3 lần. Thông số thích hợp được lựa chọn từ kết quả của thí nghiệm trước được sử dụng cho thí nghiệm kế tiếp. Kết quả của các thí nghiệm được thống kê và phân tích theo phần mềm thống kê Statgraphics Centurion XVI, phân tích phương sai ANOVA, kiểm định Duncan để kết luận sự sai khác giữa các nghiệm thức. Các phương pháp phân tích các chỉ tiêu sử dụng trong nghiên cứu được thể hiện tại Bảng 1.

\section{Bảng 1. Chỉ tiêu và các phương pháp phân tích}

\begin{tabular}{|c|c|}
\hline Chỉ tiêu & Phương pháp phân tích \\
\hline Đạm tồng số (\%) & Phương pháp Kjeldahl, TCVN 8125:2009 \\
\hline Lipid tồng số (\%) & Phương pháp Soxhlet, TCVN 8125:2009 \\
\hline Hàm lượng peroxide (\%) & Xác định theo TCVN 5777:2004 \\
\hline Tổng bazơ bay hơi (mgN/100 g) & Xác định theo TCVN 9215-2012 \\
\hline Tổng số VSV hiếu khí (CFU/g) & Xác định theo TCVN 4884:2005 \\
\hline Khả năng giữ nước (\%) & $\begin{array}{l}\text { Phương pháp nén áp lực trên giấy lọc (Grau \& Hamm, 1957; trích dẫn } \\
\text { bởi Honikel \& Hamm, 1994) }\end{array}$ \\
\hline Giá trị pH & Sử dụng pH kế, theo ISO 2917:1999(E) \\
\hline Độ ẩm $(\%)$ & Xác định bằng phương pháp NMKL số 57-1994 \\
\hline Độ trắng $\left(\mathrm{L}^{*}-3 \mathrm{x} \mathrm{b}^{*}\right)$ & $\begin{array}{l}\text { Đo bằng thiết bị đo màu NH300 (Trung Quốc) với hệ màu CIE bằng } \\
\text { đèn D65 }\end{array}$ \\
\hline Độ bền gel (g.mm) & Sử dụng máy đo cấu trúc Rheotex \\
\hline
\end{tabular}

\section{KẾT QUẢ VÀ THẢO LUẬN}

\section{1. Ảnh hưởng của nồng độ chitosan đến mật số vi sinh vật hiếu khí tổng số của sản phẩm}

Vi sinh vật hiếu khí tổng số là một trong những chỉ tiêu quan trọng để đánh giá mức độ an toàn đối với các mặt hàng thủy sản và sản phẩm thủy sản sau bảo quản. Do đó, giải pháp ứng dụng màng bao chitosan trong bảo quản sản phẩm giàu dinh dưỡng như chả cá lóc chiên là rất cần thiết. Tuy nhiên, với nồng độ dịch màng chitosan khác nhau sẽ giúp tạo nên độ dày lớp màng bao khác nhau và vì vậy có tác động đến khả năng kiểm soát vi sinh vật của màng bao. Sự thay đổi mật số vi sinh vật hiếu khí tổng số của chả cá lóc chiên được bao màng với các nồng độ chitosan khác nhau sau 1 đến 3 tuần bảo quản được thể hiện qua Bảng 2.

Bảng 2 cho thấy mật số vi sinh vật hiếu khí tổng số của các mẫu tăng dần theo thời gian bảo quản, nhưng khi nồng độ dung dịch tạo màng chitosan tăng thì mật số vi sinh vật hiếu khí tổng số giảm dần. Theo nghiên cứu của Tri and Sri (2007), nồng độ 
chitosan và thời gian tồn trữ có ảnh hưởng lớn đối với sự phát triển vi sinh vật trên sản phẩm, nồng độ chitosan càng thấp và thời gian tồn trữ càng dài thì tổng số vi khuẩn của sản phẩm sẽ tăng. Kết quả nghiên cứu còn được khẳng định bởi mẫu được bao màng chitosan luôn có khả năng hạn chế số lượng vi sinh vật tốt hơn mẫu đối chứng. Tại thời điểm bắt đầu bảo quản, vi sinh vật hiếu khí tổng số của mẫu đối chứng đạt $9 \pm 1 \mathrm{CFU} / \mathrm{g}$, tăng nhanh đến $5,90 \times 10^{2}$ (590) $\mathrm{CFU} / \mathrm{g}$ ở tuần bảo quản thứ 3 . Đối với những mẫu có bao màng với nồng độ dịch màng chitosan càng cao thì mật số vi sinh vật hiếu khí tổng số có xu hướng giảm xuống, ở nồng độ $1,5 \%$ đến $2 \%$ thì mật số vi sinh vật hiếu khí tổng số chưa vượt quá $10^{2} \mathrm{CFU} / \mathrm{g}$.

Bảng 2. Tác động của màng chitosan nồng độ khác nhau đến vi sinh vật hiếu khí tổng số của chả cá lóc chiên ở các thời điểm bảo quản khác nhau

\begin{tabular}{crrrrr}
\hline Thời gian bảo & \multicolumn{4}{c}{ Mật số vi sinh vật hiếu khí tổng số (VSVHKTS, CFU/g) } \\
\cline { 2 - 6 } quản (tuần) & Đối chứng & Chitosan 0,5\% & Chitosan 1\% & Chitosan 1,5\% & Chitosan 2\% \\
\hline 0 & $9 \pm 1$ & $27 \pm 5$ & $36 \pm 8$ & $23 \pm 1$ & $14 \pm 3$ \\
1 & $270 \pm 12$ & $130 \pm 11$ & $98 \pm 15$ & $15 \pm 2$ & $12 \pm 2$ \\
3 & $590 \pm 18$ & $530 \pm 24$ & $160 \pm 22$ & $41 \pm 2$ & $40 \pm 2$ \\
\hline
\end{tabular}

Kết quả thí nghiệm được lặp lại 3 lần

Cơ chế hoạt động chống vi sinh vật của chitosan đã được được giải thích ở nhiều nghiên cứu như sau: sự tương tác của chitosan lên màng hoặc lên các cấu tử của vách tế bào vi sinh vật làm tăng khả năng thẩm thấu của màng và sự rò rỉ chất khô từ tế bào, hoặc nhờ vào khả năng liên kết với nước và ức chế các hoạt động của enzyme thủy phân protein (Darmadji \& Izumimoto, 1994). Mặc dù chitosan có khả năng kháng khuẩn, kìm hãm sự phát triển của vi sinh vật, tuy nhiên ở nồng độ cao nhất định (từ $1,5 \%$ ) thì chitosan mới thể hiện rõ tác dụng kiểm soát vi sinh vật. Mặc dù vậy, khi nồng độ chitosan có tăng cao hơn nữa thì hiệu quả kiểm soát vi sinh vật không cũng không được cải thiện nhiều. Ngoài khả năng hạn chế sự phát triển của vi sinh vật thì khả năng chống oxy hóa, kéo dài thời gian bảo quản mát $\left(5 \pm 1^{\circ} \mathrm{C}\right)$ sản phẩm thịt cá hồi cầu vồng (Oncorhynchus mykiss) của chitosan cũng đã được khẳng định trong nghiên cứu của Chamanara et al., (2013), sản phẩm bao màng có khả năng bảo quản đến 15 ngày so với 6 ngày đối với sản phẩm không bao màng.

Xem xét kết quả trên có thể kết luận, mẫu nhúng màng chitosan ở nồng độ $1,5 \%$ có khả năng kiểm soát tốt mật số vi sinh vật, đến tuần thứ 3 chỉ đạt $41 \pm 2 \mathrm{CFU} / \mathrm{g}$ và khác biệt không đáng kể so với mẫu có nồng độ $2 \%(40 \pm 2 \mathrm{CFU} / \mathrm{g})$. Vì vậy, dung dịch màng chitosan có nồng độ chitosan $1,5 \%$ được chọn để đánh giá khả năng bảo quản ở các thí nghiệm tiếp theo.

3.2. Khả năng bảo quản chả cá lóc chiên do tác động của chitosan và sodium tripolyphosphate ở điều kiện nhiệt độ $\operatorname{lạnh}\left(4 \pm 2^{\circ} \mathrm{C}\right)$

Ở điều kiện nhiệt độ bảo quản lạnh, khả năng phát triển của vi sinh vật gây hư hỏng vẫn còn ở mức cao, nên khả năng kiểm soát vi sinh vật của màng bao có vai trò hết sức quan trọng. Trong nghiên cứu, màng bao chitosan với nồng độ $1,5 \%$ đã được sử dụng, đồng thời, để nâng cao hiệu quả kiểm soát của của rào cản này, muối sodium tripolyphosphate đã được bổ sung với nồng độ $0,2 \%$ vào dung dịch chitosan trước khi nhúng tạo màng để tạo hệ gel mang các chuỗi ion âm (nanochitosan) có khả năng hạn chế sự phát triển của vi sinh vật. Nhiều nghiên cứu cũng đã chứng minh hỗn hợp này không độc và khả năng tạo gel cũng nhanh chóng (De Moura et al., 2009). Ảnh hưởng của việc sử dụng màng chitosan có và không có sự kết hợp với sodium tripolyphosphate đến sự thay đổi chỉ tiêu vi sinh hiếu khí tồng số của chả cá lóc chiên ở các thời điểm bảo quản khác được thể hiện ở Bảng 3.

Bảng 3 cho thấy trong điều kiện bảo quản lạnh $\left(4 \pm 2^{\circ} \mathrm{C}\right)$ mật số vi sinh vật hiếu khí tổng số tăng liên tục theo thời gian bảo quản ở tất cả các mẫu. Với độ ẩm cao, giàu dinh dưỡng và hàm lượng protein tổng số cao lên đến trên $20 \%$ nên chả cá lóc chiên là môi trường rất thuận lợi cho sự phát triển của vi sinh vật. Ở điều kiện bảo quản không bao màng (mẫu đối chứng), mật số vi sinh vật hiếu khí tổng số phát triển nhanh chóng, lên đến hơn $10^{5} \mathrm{CFU} / \mathrm{g}$ sau hai tháng bảo quản, vượt quá quy định cho phép của Bộ Y tế. Riêng hai loại màng bao chitosan và chitosan có hỗ trợ của STPP (nanochitosan) đã thể hiện hiệu quả kiểm soát sự phát triển của vi sinh vật, đến tuần bảo quản thứ 8 mật số vi sinh vật hiếu khí tổng số vẫn còn thấp hơn so với quy định của Bộ Y tế $\left(5,9 \times 10^{3}\right.$ $\mathrm{CFU} / \mathrm{g}$ đối với màng chitosan và $3,2 \times 10^{3} \mathrm{CFU} / \mathrm{g}$ đối với mẫu bao màng chitosan có hỗ trợ của STPP).

Ngoài ra, kết quả cũng đã cho thấy sự kết hợp với STPP đã nâng cao hiệu quả kiểm soát vi sinh vật của màng chitosan, điều này cũng đã được chứng 
minh trong nghiên cứu của Du et al. (2009), việc phân bố của STPP trên màng chitosan đã tạo nên tính chất vật lý và hóa học độc đáo cho màng. Không chỉ có tiềm năng ức chế vi sinh vật hiếu khí tổng số, màng chitosan có hỗ trợ của STPP còn có khả năng kiểm soát sự phát triển của nhiều vi sinh vật gây hư hỏng khác, chẳng hạn vi sinh vật thủy phân protein, vi sinh vật ưa lạnh, coliform và các vi sinh vật gây hư hỏng khác (Entsar et al., 2012). Do vậy, xét về vấn đề an toàn vi sinh thì sử dụng màng ăn được kết hợp với STPP $(1,5 \%$ chitosan $+0,2 \% \mathrm{STPP})$ có tiềm năng rất lớn trong việc hạn chế sự phát triển của vi sinh vật trên sản phẩm chả cá lóc chiên.

\section{Bảng 3. Tác động của màng bảo quản đến độ bền gel và vi sinh hiếu khí tổng số của chả cá lóc chiên theo thời gian bảo quản lạnh}

\begin{tabular}{lcrr}
\hline Phụ gia & Tuần & Độ bền gel (g.mm) & VSVHKTS (CFU/g) \\
\hline \multirow{3}{*}{ Đối chứng } & 0 & $9485 \pm 381^{\mathrm{ef}}$ & $(0,90 \pm 0,2) \times 10^{1}$ \\
& 2 & $9256 \pm 232^{\mathrm{cde}}$ & $(4,40 \pm 0,3) \times 10^{2}$ \\
& 4 & $8947 \pm 523^{\mathrm{bcd}}$ & $(2,40 \pm 0,2) \times 10^{3}$ \\
& 6 & $8766 \pm 458^{\mathrm{b}}$ & $(1,20 \pm 0,1) \times 10^{4}$ \\
& 8 & $7801 \pm 419^{\mathrm{a}}$ & $(2,60 \pm 0,4) \times 10^{5}$ \\
\hline & 0 & $8503 \pm 216^{\mathrm{b}}$ & $(2,30 \pm 0,1) \times 10^{1}$ \\
Chitosan $1,5 \%$ & 2 & $9892 \pm 271^{\mathrm{f}}$ & $(1,80 \pm 0,2) \times 10^{1}$ \\
& 4 & $9400 \pm 356^{\mathrm{de}}$ & $(2,90 \pm 0,2) \times 10^{2}$ \\
& 6 & $8957 \pm 381^{\mathrm{bcd}}$ & $(8,40 \pm 0,3) \times 10^{2}$ \\
& 8 & $8874 \pm 279^{\mathrm{bc}}$ & $(5,90 \pm 0,4) \times 10^{3}$ \\
Chitosan $1,5 \%+$ STPP $0,2 \%$ & 0 & $8640 \pm 586^{\mathrm{b}}$ & $(1,80 \pm 0,2) \times 10^{1}$ \\
& 2 & $9879 \pm 222^{\mathrm{f}}$ & $(2,30 \pm 0,1) \times 10^{1}$ \\
& 4 & $9543 \pm 329^{\mathrm{ef}}$ & $(3,00 \pm 0,2) \times 10^{2}$ \\
& 6 & $9361 \pm 286^{\mathrm{de}}$ & $(6,80 \pm 0,4) \times 10^{2}$ \\
& 8 & $8954 \pm 394^{\mathrm{bcd}}$ & $(4,20 \pm 0,3) \times 10^{3}$ \\
\hline
\end{tabular}

(Thi nghiệm được lặp lại 3 làn, các chũ cái giống nhau trong cùng một cột biểu thị sụ không khác biệt về thống kê của các nghiệm thức khảo sát ở độ tin cậy 95\%)

Mặc dù lợi thế về an toàn vi sinh đã được khẳng định nhưng các chỉ tiêu chất lượng, cảm quan khác của chả cá lóc chiên sau bảo quản cũng cần được quan tâm. Trong nghiên cứu cấu trúc của chả cá lóc qua thời gian bảo quản, giá trị độ bền gel đã được sử dụng, đây là tích số của độ biến dạng và lực phá vỡ của sản phẩm.

Độ bền gel của chả cá lóc chiên được thể hiện ở Bảng 3 cho thấy có sự suy giảm khá nhanh theo thời gian bảo quản ở điều kiện nhiệt độ lạnh. Mẫu chả cá lóc sau chiên có độ bền gel 9.500 g.mm đối với mẫu không bao màng trước khi đưa vào bảo quản. Riêng đối với mẫu có nhúng màng bao, độ bền gel ở tuần trước khi đưa vào bảo quản (tuần 0 ) có giá trị rất thấp, nguyên nhân này có thể giải thích do tác động của việc nhúng tạo màng bao. Mẫu chả cá sau chiên có bề mặt tương đối cứng chắc, khi nhúng màng thì quá trình ngấm dung dịch bao màng trên bề mặt đã làm cho cấu trúc bề mặt sản phẩm chả yếu đi. Tuy nhiên, vấn đề suy giảm cấu trúc này mất đi sau 2 tuần bảo quản, lúc này lớp màng bao đã ổn định và cấu trúc sản phẩm trở lại bình thường. Do đó, với những biến đổi diễn ra như thế, trường hợp chả cá lóc không qua bảo quản (sử dụng ngay) đôi khi việc nhúng màng lại có tác động tiêu cực hơn.

Xét về sự thay đổi của độ bền gel qua các thời điểm khác nhau, kết quả nghiên cứu cho thấy màng bao chitosan đã cải thiện đáng kể đặc tính này của sản phẩm chả cá lóc chiên. Ngoài hiệu quả hạn chế sự biến đổi đặc tính gel của protein do các biến đổi không mong muốn, cấu trúc màng của chitosan tương đối vững chắc cũng một phần làm tăng độ bền gel của chả cá lóc. Bên cạnh đó, khả năng giữ nước là thông số có ý nghĩa rất lớn đối với các sản phẩm mang đặc tính gel protein, nó chính là thông số chất lượng của sản phẩm. Khả năng giữ nước tăng hay giảm thể hiện sự biến đổi của thành phần protein của sản phẩm. Sự biến tính protein của sản phẩm làm protein mất đặc tính chức năng, khả năng tạo gel giảm, nên đặc tính gel của sản phẩm cũng giảm theo. Kết quả sự thay đồi khả năng giữ nước, độ trắng và $\mathrm{pH}$ của chả được thể hiện qua Bảng 4.

Kết quả Bảng 4 cho thấy, sự biến tính của protein trong sản phẩm chả cá lóc chiên diễn ra khá nhanh khi thời gian bảo quản dài đối với mẫu đối chứng (mẫu không có màng bao). Khả năng giữ nước của sản phẩm không thay đổi nhiều trong giai đoạn đầu 
của quá trình bảo quản (khoảng 4 tuần bảo quản đầu), đồng thời trong giai đoạn này sự khác biệt giữa các mẫu cũng không có ý nghĩa về mặt thống kê. Thế nhưng, khi so sánh với chế độ bảo quản không bao màng và bao màng chitosan thì mẫu bao màng chitosan kết hợp với STPP cho khả năng giữ nước cao hơn và duy trì tốt hơn, hiệu quả bảo quản thể hiện ở những giai đoạn bảo quản cuối (tuần 6 và 8 ). Khả năng giữ nước của mẫu đối chứng tại tuần bảo quản thứ 8 là $86,81 \pm 0,68 \%$, trong khi khả năng giữ nước của mẫu chitosan là $91,14 \pm 0,49 \%$ và khả năng giữ nước của mẫu chitosan kết hợp STPP là $92,19 \pm 0,42 \%$, nguyên nhân có sự khác biệt có thể do lớp màng trở thành hàng rào vững chắc ngăn cản quá trình thoát ẩm của thực phẩm. Bên cạnh đó, $\mathrm{pH}$ của mẫu nanochitosan cao hơn giá trị $\mathrm{pH}$ của các mẫu còn lại do STPP được bổ sung vào có khả năng nâng $\mathrm{pH}$ của chả, giúp sản phẩm giữ nước tốt hơn. Điều này có thể được giải thích là do màng bao chitosan kết hợp với STPP có khả năng hạn chế các tiến trình oxy hóa, làm biến tính protein.

Bảng 4. Sự tác động của màng bảo quản đến khả năng giữ nước (WHC), độ trắng và pH của chả cá lóc chiên theo thời gian bảo quản lạnh

\begin{tabular}{|c|c|c|c|c|}
\hline Phụ gia & Tuần & WHC (\%) & Độ trắng (WI, \%) & pH \\
\hline \multirow{5}{*}{ Đối chứng } & 0 & $94,09 \pm 0,47^{g}$ & $72,85 \pm 0,28^{\mathrm{e}}$ & $6,53 \pm 0,56^{\mathrm{efg}}$ \\
\hline & 2 & $93,11 \pm 0,52^{\text {efg }}$ & $72,20 \pm 1,13^{\text {de }}$ & $6,67 \pm 0,56^{\mathrm{h}}$ \\
\hline & 4 & $91,57 \pm 0,62^{\mathrm{cd}}$ & $70,68 \pm 1,39^{\text {bcd }}$ & $6,60 \pm 0,10^{\mathrm{fgh}}$ \\
\hline & 6 & $90,13 \pm 0,76^{\mathrm{b}}$ & $69,42 \pm 0,62^{\mathrm{ab}}$ & $6,30 \pm 0,10^{b}$ \\
\hline & 8 & $86,81 \pm 0,68^{a}$ & $67,96 \pm 0,76^{\mathrm{a}}$ & $5,70 \pm 0,56^{\mathrm{a}}$ \\
\hline \multirow{5}{*}{ Chitosan $1,5 \%$} & 0 & $93,99 \pm 0,11^{\mathrm{g}}$ & $72,52 \pm 0,91^{\mathrm{e}}$ & $6,40 \pm 0,00^{\text {bcd }}$ \\
\hline & 2 & $93,57 \pm 0,54^{\mathrm{fg}}$ & $72,51 \pm 0,61^{\mathrm{e}}$ & $6,50 \pm 0,10^{\text {def }}$ \\
\hline & 4 & $92,81 \pm 0,52^{\mathrm{ef}}$ & $71,57 \pm 0,95^{\text {cde }}$ & $6,57 \pm 0,06^{\mathrm{fgh}}$ \\
\hline & 6 & $91,82 \pm 0,63^{\mathrm{cd}}$ & $70,65 \pm 0,80^{\mathrm{bcd}}$ & $6,43 \pm 0,06^{\text {cde }}$ \\
\hline & 8 & $91,14 \pm 0,20^{c}$ & $70,45 \pm 0,58^{\mathrm{bc}}$ & $6,33 \pm 0,06^{\mathrm{bc}}$ \\
\hline \multirow{5}{*}{$\begin{array}{l}\text { Chitosan } 1,5 \%+\text { STPP } \\
0,2 \%\end{array}$} & 0 & $94,12 \pm 0,69^{\mathrm{h}}$ & $72,34 \pm 1,08^{\text {de }}$ & $6,50 \pm 0,00^{\text {def }}$ \\
\hline & 2 & $93,94 \pm 0,67^{\mathrm{g}}$ & $72,86 \pm 0,72^{\mathrm{e}}$ & $6,53 \pm 0,56^{\mathrm{efg}}$ \\
\hline & 4 & $93,24 \pm 0,60^{\mathrm{fg}}$ & $72,16 \pm 0,89^{\text {cde }}$ & $6,63 \pm 0,56^{\mathrm{gh}}$ \\
\hline & 6 & $92,90 \pm 0,45^{\text {ef }}$ & $71,12 \pm 1,11^{\text {cde }}$ & $6,57 \pm 0,56^{\mathrm{fgh}}$ \\
\hline & 8 & $92,19 \pm 0,42^{\text {de }}$ & $70,61 \pm 1,09^{\mathrm{bcd}}$ & $6,50 \pm 0,10^{\text {def }}$ \\
\hline
\end{tabular}

(Các chũu cái giống nhau trong cùng một cột biểu thị sụ không khác biệt về thống kê của các nghiệm thức khảo sát ở độ tin cây 95\%)

Hiệu quả duy trì khả năng giữ nước của màng chitosan kết hợp STPP cũng được giải thích thông qua khả năng duy trì giá trị $\mathrm{pH}$ của sản phẩm. Chả cá lóc chiên bao màng chitosan có sự hỗ trợ của STPP có $\mathrm{pH}$ ổn định trong suốt 8 tuần ở điều kiện bảo quản lạnh (Bảng 4), so với mẫu không bao màng và bao màng chitosan thì $\mathrm{pH}$ được duy trì ổn định hơn. Giá trị pH của mẫu đối chứng có sự giảm mạnh hơn khi so sánh với mẫu chả được nhúng màng, đến tuần thứ 6 có sự khác biệt ý nghĩa thống kê $(\mathrm{pH}$ tại tuần bảo quản thứ 6 đạt $6,30 \pm 0,10$ và tuần thứ 8 đạt $5,70 \pm 0,56)$, điều này cho thấy mẫu đối chứng bắt đầu có dấu hiệu hư hỏng. Đối với mẫu nhúng màng chitosan kết hợp STPP thì giá trị pH cao hơn khi so với mẫu nhúng màng chitosan, điều này có thể là do những đặc điểm cơ bản của sodium tripolyphosphate, có khả năng nâng $\mathrm{pH}$ sản phẩm. Sự giảm giá trị $\mathrm{pH}$ có thể được giải thích là do kết quả từ sự phân hủy protein, giải phóng phosphoride acid và lactic acid xảy ra trong quá trình bảo quản lạnh (Singh \& Balange, 2005; Duan et al., 2010). Sự gia tăng của giá trị pH đã được cho là do sự sản sinh amoniac và trimethylamine bởi các enzyme nội bào hoặc vi sinh vật (Manat et al., 2005; Fan et al., 2009). Tùy mức độ của các yếu tố gây tăng giảm khác nhau mà quyết định đến $\mathrm{pH}$ của sản phẩm, sự ổn định của $\mathrm{pH}$ sản phẩm trong suốt quá trình bảo quản có thể do hiệu quả kiểm soát sự phát triển của vi sinh vật và các biến đổi gây hư hỏng diễn ra trên sản phẩm.

Độ trắng $(\mathrm{WI})$ của sản phẩm từ kết quả ở Bảng 4 cũng có xu hướng giảm dần qua các tuần bảo quản. Độ trắng của mẫu không nhúng màng có sự giảm đáng kể so với độ trắng của mẫu đã nhúng màng, điều này có thể giải thích do sự oxy hóa protein và sự mất ẩm của mẫu đối chứng trong quá trình bảo quản, (ngay cả khi có sử dụng bao bì $\mathrm{PA}$ ) cao hơn khi so với mẫu được bao màng chitosan và chitosan có bổ trợ STPP. Điều kiện bảo quản sử dụng màng bao đã giúp hạn chế các quá trình oxy hóa diễn ra, giữ được độ trắng mặt trong của sản phẩm trong quá trình bảo quản. Ngoài ra, sự mất ẩm ở những mẫu 
bảo quản có sử dụng màng bao được kiểm soát tốt hơn, lượng ẩm mất đi ít hơn, ngoài việc ít xảy ra sự biến tính protein còn giữ được màu sắc sản phẩm tốt hơn (độ trắng sản phẩm được duy trì). Bên cạnh đó, sự oxy hóa lipid cũng làm cho màu sắc của sản phẩm trở nên sậm hơn.

Để quan sát tốt hơn sự biến đổi gây hư hỏng sản phẩm trong suốt quá trình bảo quản, hai chỉ tiêu thể hiện sự hư hỏng của sản phẩm bao gồm tổng nitơ base bay hơi (TVBN) và chỉ số peroxide được theo dõi, kết quả thể hiện ở Bảng 5 và Hình 1 .

Tổng nitơ base bay hơi hình thành trong thủy sản và sản phẩm thủy sản được sử dụng như một chỉ thị của sự phân hủy gây ra bởi vi sinh vật và quá trình tự phân của protein trong suốt quá trình bảo quản. Kết quả Bảng 5 và Hình 1 cho thấy, hàm lượng TVBN tăng liên tục theo thời gian bảo quản, giá trị TVBN ban đầu ở tất cả các mẫu không có sự khác biệt nhiều, mặc dù mẫu đối chứng (không bao màng) có giá trị thấp hơn. Theo thời gian bảo quản, mâ̂u không sử dụng màng bao có hàm lượng TVBN tăng nhanh, từ $18,03 \pm 0,39 \mathrm{mgN} / 100 \mathrm{~g}$ trước khi đưa vào bảo quản lên đến $24,60 \pm 0,34 \mathrm{mgN} / 100 \mathrm{~g}$ ở tuần bảo quản thứ 8 (tăng khác biệt về thống kê sau mỗi hai tuần bảo quản).

Bảng 5. Sự tác động của màng bảo quản đến chỉ số peroxide của chả cá lóc chiên theo thời gian bảo quản lạnh

\begin{tabular}{crrr}
\hline Thời gian bảo & \multicolumn{3}{c}{ Chỉ số peroxide (mEq/kg) } \\
\cline { 2 - 4 } quản (tuần) & Đối chứng & Chitosan 1,5\% & Chitosan 1,5\% + STPP 0,2\% \\
\hline 0 & $0,05 \pm 0,01^{\mathrm{aA}}$ & $0,07 \pm 0,01^{\mathrm{aA}}$ & $0,06 \pm 0,01^{\mathrm{aA}}$ \\
2 & $0,11 \pm 0,01^{\mathrm{bAB}}$ & $0,09 \pm 0,01^{\mathrm{aA}}$ & $0,08 \pm 0,01^{\mathrm{abA}}$ \\
4 & $0,18 \pm 0,01^{\mathrm{cC}}$ & $0,15 \pm 0,01^{\mathrm{bB}}$ & $0,08 \pm 0,01^{\mathrm{abA}}$ \\
6 & $0,80 \pm 0,06^{\mathrm{dC}}$ & $0,43 \pm 0,04^{\mathrm{cB}}$ & $0,14 \pm 0,01^{\mathrm{cA}}$ \\
8 & $1,62 \pm 0,11^{\mathrm{eC}}$ & $0,74 \pm 0,06^{\mathrm{dB}}$ & $0,45 \pm 0,02^{\mathrm{dA}}$ \\
\hline
\end{tabular}

(Các chũ cái in thuờng giống nhau trong cùng một cột biểu thị sư không khác biệt về thống kê của các nghiệm thức khảo sát ở độ tin câyy 95\%; các chữ cái in hoa giống nhau trong cùng một hàng biểu thị sụ không khác biệt về thống kê của các nghiệm thức khảo sát ở độ tin cậy 95\%)

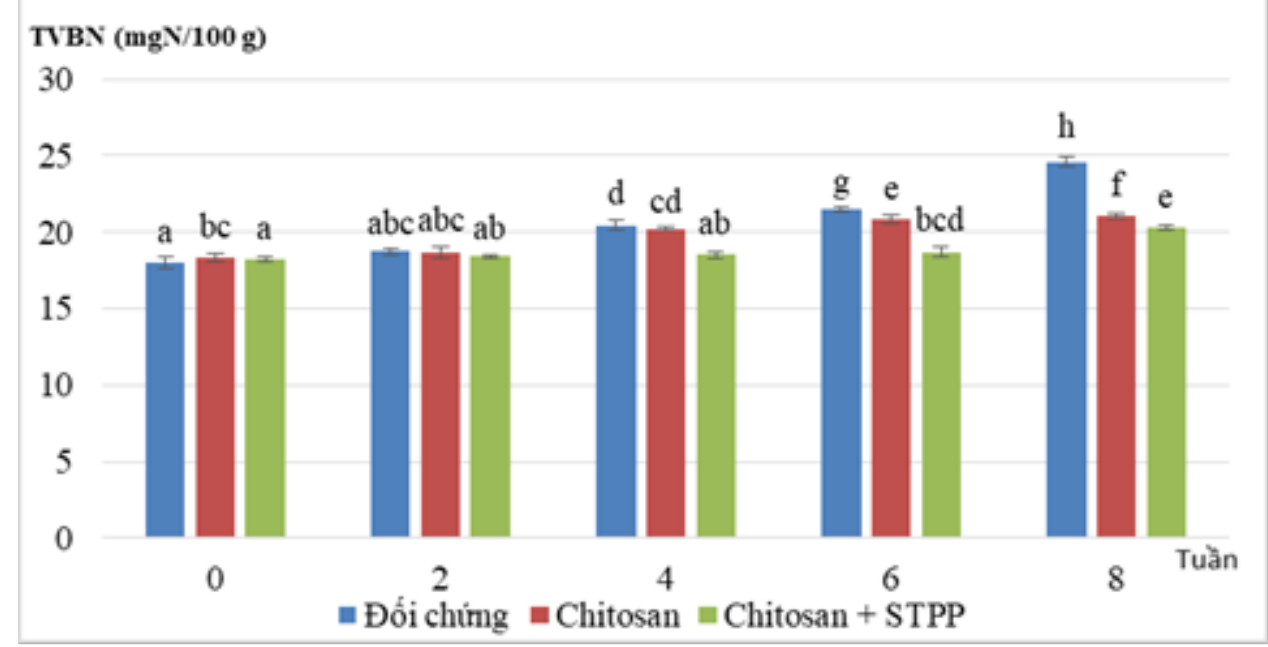

\section{Hình 1. Đồ thị biểu diễn sự thay đổi hàm lượng TVBN trong quá trình bảo quản chả cá lóc chiên của các loại màng bao khác nhau}

Kết quả thay đổi hàm lượng TVBN là phù hợp với sự phát triển của mật số vi sinh vật trong sản phẩm (Bảng 4). Sự phát triển nhanh chóng của mật số vi sinh vật là nguyên nhân của việc gia tăng hàm lượng TVBN, cho thấy dấu hiệu hư hỏng của sản phẩm (Connell, 1990).
Nghiên cứu của Jeon et al. (2002) cho thấy, việc hình thành TVBN cũng giảm đi đáng kể trong quá trình tồn trữ sản phẩm thủy sản khi sử dụng màng bao chitosan. Kết quả phân tích sự biến đổi của hàm lượng TVBN theo thời gian bảo quản cũng cho thấy, 
mẫu bao màng chitosan kết hợp STPP có sự gia tăng hàm lượng TVBN chậm hơn so với mẫu sử dụng màng chitosan. Điều này chứng tỏ, sự hiện diện của STPP đã có hiệu quả cao trong việc hạn chế sự hư hỏng xảy ra bởi vi khuẩn, sự phân hủy protein thành các hợp chất bay hơi trong quá trình bảo quản. Nghiên cứu tương tự của Osheba et al. (2013) cũng đã chứng minh, màng chitosan kết hợp STPP có khả năng kiểm soát sự phân hủy của sản phẩm cũng như duy trì chất lượng trong suốt thời gian bảo quản, đặc biệt là kiểm soát sự phát triển của vi sinh vật gây hư hỏng.

Sự thay đổi chỉ số peroxide của chả cá lóc chiên theo thời gian bảo quản lạnh cũng được thể hiện ở Bảng 5 , chỉ số này cũng tăng dần theo thời gian bảo quản cả mẫu đối chứng và bao màng. Mẫu đối chứng có sự gia tăng chỉ số peroxide đáng kể qua các tuần bảo quản, ở tuần thứ 8 peroxide đạt $1,62 \pm 0,11$ $\mathrm{mEq} / \mathrm{kg}$, trong khi mẫu được bao màng chitosan chỉ ở mức $0,74 \pm 0,06 \mathrm{mEq} / \mathrm{kg}$ và mẫu được bao màng chitosan kết hợp STPP chỉ 0,45 $\pm 0,02 \mathrm{mEq} / \mathrm{kg}$. Điều này cho thấy, theo thời gian bảo quản thì mức độ ôi hóa của mẫu đối chứng ngày càng cao, do đó khả năng bảo quản sẽ kém hơn. Khi so sánh với mẫu đối chứng thì mẫu chả được nhúng màng chitosan và chitosan kết hợp STPP có chỉ số peroxide thấp hơn, do chitosan có khả năng hấp thụ các phân tử chất béo lên bề mặt của nó làm cho chất béo không bị oxy hóa trong quá trình bảo quản, bởi chitosan mang điện tích dương còn acid béo mang điện tích âm, do đó có sự liên kết hóa học giữa hai hợp chất này (Morachis-Valdez et al., 2017). Bên cạnh đó, khi chả được nhúng màng chitosan và chitosan kết hợp
STPP sẽ tạo thành lớp màng bao bên ngoài sản phẩm. Lớp màng này hoạt động như một màng ngăn giữa sản phẩm với môi trường xung quanh nó, do đó làm giảm sự khuếch tán oxy từ môi trường đến bề mặt vào trong sản phẩm nên lipid không bị oxy hóa nhiều. Theo nghiên cứu của Jeon et al. (2002) đã cho thấy màng chitosan có khả năng hạn chế sự oxy hóa chất béo, như một tác nhân chống sự xâm nhập của oxy. Sathivel (2005) cũng đã chứng minh rằng, cá hồi fillet nhúng màng chitosan với nồng độ $1 \%$ và $2 \%$ giúp hạn chế sự oxy hóa lipid hơn so với mẫu đối chứng sau 3 tháng tồn trữ lạnh đông.

\section{3. Ảnh hưởng của việc sử dụng chitosan và sodium tripolyphosphate đến khả năng bảo quản lạnh đông chả cá lóc chiên}

Điều kiện bảo quản lạnh đông ở nhiệt độ $20 \pm 2^{\circ} \mathrm{C}$ sẽ hạn chế được rất nhiều những biến đổi gây hư hỏng đối với sản phẩm. Tuy nhiên, do chả là sản phẩm có giá trị dinh dưỡng rất cao đồng thời đặc tính gel của sản phẩm phụ thuộc nhiều vào tính chất chức năng của protein, nên những biến đổi xảy ra đối với protein trong quá trình bảo quản đều có ảnh hưởng đến chất lượng sản phẩm, nhất là quá trình oxy hóa hay trong tiến trình biến tính protein. Tác động bảo vệ cũng như khả năng kéo dài thời gian bảo quản sản phẩm dạng gel protein của màng ăn được chitosan đã được chứng minh trong nhiều nghiên cứu (Entsar et al., 2012; Osheba et al., 2013). Kết quả đánh giá ảnh hưởng của các loại màng chitosan đối với khả năng giữ nước (WHC) của chả cá lóc chiên bảo quản ở điều kiện lạnh đông được thể hiện ở Hình 2.

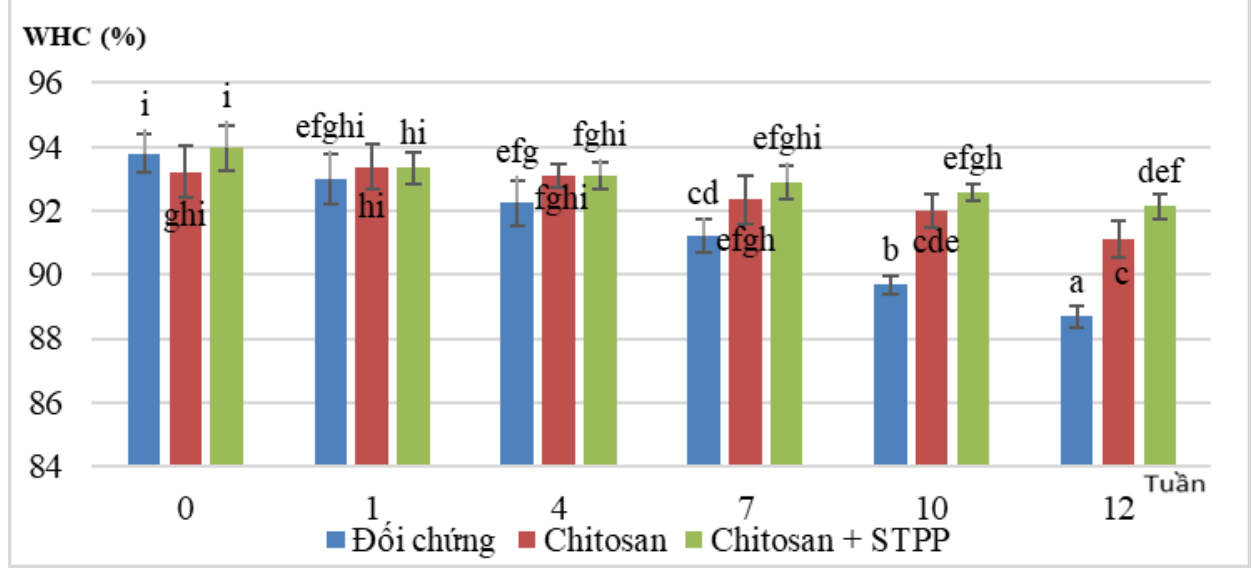

Hình 2. Đồ thị biểu diễn sự thay đổi khả năng giữ nước trong quá trình trữ đông chả cá lóc chiên của các loại màng bao khác nhau 
Kết quả ở Hình 2 cho thấy, khả năng giữ nước của sản phẩm không bao màng hay bao màng chitosan được bảo quản lạnh đông đều giảm dần theo thời gian bảo quản. Mẫu được bảo quản lạnh đông có khả năng giữ nước giảm do trong quá trình trữ đông một số tinh thể đá tiếp tục hình thành, làm đứt các liên kết trong cấu trúc sản phẩm, giảm khả năng giữ nước (Nguyễn Văn Mười, 2007), tuy nhiên mức độ giảm là không đáng kể. Giá trị WHC của mẫu đối chứng tại tuần bảo quản thứ 12 là $88,69 \pm 0,34 \%$, mẫu được bao màng chitosan là $91,11 \pm 0,58 \%$ và mẫu được bao màng chitosan kết hợp STPP là $92,13 \pm 0,37 \%$. Điều này cho thấy mẫu đối chứng được bảo quản mát và cả mẫu lạnh đông đều có khả năng giữ nước giảm mạnh hơn so với mẫu được nhúng màng, do không có lớp màng bảo vệ làm cho quá trình thoát ẩm và những biến đổi không mong muốn của thực phẩm diễn ra mạnh mẽ hơn. Trong nghiên cứu, sau khi trữ đông, tiến hành rã đông thì sự mất nước và hao hụt khối lượng của cá giảm hơn trường hợp không sử dụng chitosan. Ngoài ra, kết quả ở Hình 2 cũng cho thấy, khả năng giữ nước của mẫu nhúng màng chitosan kết hợp STPP có phần tốt hơn so với mẫu được nhúng màng chitosan, bởi khi bổ sung sodium tripolyphosphate, pH sẽ được nâng lên đáng kể (khoảng 0,2 đển 0,5 đơn vị), điều này góp phần làm tăng khả năng giữ nước của sản phẩm (Nguyễn Văn Mười \& Trần Thanh Trúc, 2014).

Bảng 6. Sự tác động của màng chitosan và nhiệt độ trữ đông đến độ bền gel và vi sinh hiếu khí tổng số của chả cá lóc chiên theo thời gian bảo quản

\begin{tabular}{|c|c|c|c|}
\hline Phụ gia & Tuần & Độ bền gel (g.mm) & VSVHKTS (CFU/g) \\
\hline \multirow{6}{*}{ Đối chứng } & 0 & $9978 \pm 258^{\mathrm{h}}$ & $(0,90 \pm 0,1) \times 10^{1}$ \\
\hline & 1 & $9677 \pm 205^{\text {efgh }}$ & $(0,50 \pm 0,1) \times 10^{1}$ \\
\hline & 4 & $9659 \pm 213^{\text {efgh }}$ & $(1,80 \pm 0,2) \times 10^{1}$ \\
\hline & 7 & $9243 \pm 298^{\text {cde }}$ & $(5,50 \pm 0,3) \times 10^{1}$ \\
\hline & 10 & $9111 \pm 258^{\mathrm{bcd}}$ & $\left(1,40 \pm 0,2 \times 10^{2}\right.$ \\
\hline & 12 & $8980 \pm 174^{\mathrm{abc}}$ & $(6,20 \pm 0,2) \times 10^{2}$ \\
\hline \multirow{6}{*}{ Chitosan } & 0 & $8625 \pm 356^{\mathrm{a}}$ & $(2,30 \pm 0,1) \times 10^{1}$ \\
\hline & 1 & $9951 \pm 312^{\mathrm{h}}$ & $(0,90 \pm 0,1) \times 10^{1}$ \\
\hline & 4 & $9768 \pm 334^{\text {fgh }}$ & $(0,50 \pm 0,1) \times 10^{1}$ \\
\hline & 7 & $9585 \pm 362^{\text {efgh }}$ & $(1,80 \pm 0,1) \times 10^{1}$ \\
\hline & 10 & $9439 \pm 345^{\text {def }}$ & $(3,20 \pm 0,2) \times 10^{1}$ \\
\hline & 12 & $9379 \pm 314^{\text {cdef }}$ & $(6,40 \pm 0,5) \times 10^{1}$ \\
\hline \multirow{6}{*}{ Chitosan + STPP } & 0 & $8727 \pm 340^{\mathrm{ab}}$ & $(1,80 \pm 0,2) \times 10^{1}$ \\
\hline & 1 & $9890 \pm 144^{\text {cde }}$ & $(0,50 \pm 0,1) \times 10^{1}$ \\
\hline & 4 & $9745 \pm 675^{\text {fgh }}$ & $(2,70 \pm 0,2) \times 10^{1}$ \\
\hline & 7 & $9664 \pm 375^{\text {efgh }}$ & $(0,90 \pm 0,1) \times 10^{1}$ \\
\hline & 10 & $9635 \pm 381^{\text {efgh }}$ & $(1,30 \pm 0,2) \times 10^{1}$ \\
\hline & 12 & $9466 \pm 242^{\text {defg }}$ & $(3,20 \pm 0,2) \times 10^{1}$ \\
\hline
\end{tabular}

(Thi nghiệm được lặp lại 3 làn, các chũ cái giống nhau trong cùng một cột biểu thị sụ không khác biệt về thống kê của các nghiệm thức khảo sát ở độ tin cậy 95\%)

Cùng với sự giảm khả năng giữ nước, độ bền gel của chả cá lóc chiên trữ đông cũng giảm dần theo thời gian bảo quản. Kết quả Bảng 6 cho thấy, độ bền gel của mẫu đối chứng (không bao màng) giảm đáng kể, từ tuần thứ 7 (9242 \pm 298 g.mm) có sự khác biệt có ý nghĩa thống kê so với mẫu tuần $0(9978 \pm 258$ g.mm). Độ bền gel ở mẫu được bao màng chitosan kết hợp STPP tuy giảm nhưng khi so với mẫu bao màng chitosan và mẫu không bao màng thì mức độ giảm thấp hơn, số liệu độ bền gel tại tuần bảo quản thứ 12 của mẫu đối chứng là $8980 \pm 174$ g.mm, không khác biệt so với độ bền gel của mẫu được bao màng chitosan là $9379 \pm 314$ g.mm nhưng khác biệt có ý nghĩa thống kê đối với mẫu được bao màng chitosan kết hợp STPP (9466 \pm 242 g.mm).

Tất cả điều đó cho thấy, màng bao chitosan có sự hỗ trợ của STPP duy trì khá tốt độ bền gel của chả cá lóc chiên, bởi STPP có chức năng cải thiện đặc tính cấu trúc của sản phẩm bằng cách tăng khả năng giữ nước của sản phẩm. Tất cả điều này cho thấy, đặc tính gel của sản phẩm chả được duy trì tốt trong điều kiện sử dụng màng kết hợp với bảo quản ở nhiệt độ thấp và đặc biệt là màng chitosan được bổ trợ STPP. Hơn thế nữa, tác động hạn chế sự oxy hóa lipid của quá trình lạnh đông và bao màng cũng là yếu tố quan trọng quyết định đến khả năng bảo quản 
và đặc biệt ngăn cản sự oxy hóa protein tiếp theo, giúp duy trì đặc tính gel của chả cá lóc chiên.

Về chỉ tiêu an toàn vi sinh, kết quả Bảng 6 cho thấy, qua các tuần bảo quản tất cả các mẫu có bao màng hay không bao màng đều có mật số vi sinh hiếu khí tổng số tăng. Tuy nhiên, so với điều kiện bảo quản mát thì mức độ tăng không cao, các mẫu đều đạt tiêu chuẩn về an toàn vi sinh theo quy định của Bộ Y tế (chưa vượt quá $10^{5} \mathrm{CFU} / \mathrm{g}$ ). Tồng số vi sinh của mẫu đối chứng tại tuần bảo quản thứ 12 là $(6,20 \pm 0,2) \times 10^{2} \mathrm{CFU} / \mathrm{g}$, mẫu được bao màng chitosan là $(6,40 \pm 0,5) \times 10^{1} \mathrm{CFU} / \mathrm{g}$ và mẫu được bao màng chitosan kết hợp STPP là $(3,20 \pm 0,2) \times 10^{1}$ $\mathrm{CFU} / \mathrm{g}$. Điều này cho thấy trong thời gian bảo quản, màng chitosan và màng chitosan được bổ trợ STPP kết hợp với nhiệt độ thấp đã mang lại hiệu quả ức chế vi sinh vật rất cao. Bởi vì, chitosan là một polysaccharide mang điện tích dương còn màng vi sinh vật chứa protein có tính lưỡng cực, khi chitosan tiếp xúc với protein thì sẽ xảy ra sự tương tác giữa các điện tích trái dấu. Chitosan có thể kêt hợp với protein trực tiếp hoặc gián tiếp thông qua các phân tử nước. Do đó, vi sinh vật sẽ bị giữ bởi chitosan, lực tương tác giữa các nhóm $\mathrm{NH}_{3}{ }^{+}$của các phân tử chitosan với các nhóm $\mathrm{COO}^{-}$trên bề mặt của vi sinh vật có thể dẫn đến phá vỡ cấu trúc của màng tế bào vi sinh vật, làm cho vi sinh vật bị chết, hơn nữa lớp phủ chitosan hoạt động như một rào cản oxy và do đó ức chế sự tăng trưởng của vi khuẩn hiếu khí (Shahidi et al., 1999; Devlieghere et al., 2004), tuy nhiên chitosan có hoạt tính kháng khuẩn và thời gian được hấp thu chậm hơn so với màng chitosan có STPP hỗ trợ. Điều này chứng tỏ rằng, màng chitosan kết hợp STPP cho khả năng ức chế vi sinh vật và kéo dài thời gian bảo quản của chả tốt nhất. Từ kết quả phân tích trên, đối với sản phẩm chả cá lóc chiên nếu được bảo quản bằng cách bao màng chitosan ở nồng độ $1,5 \%$ hoặc chitosan 1,5\% kết hợp STPP $0,2 \%$ trong thời gian 2 phút ở điều kiện bảo quản lạnh đông $-20 \pm 2^{\circ} \mathrm{C}$ thì sản phẩm có thể bảo quản được trong 12 tuần mà vẫn đạt tiêu chuẩn về vi sinh. Nhưng khi xét về khả năng duy trì đặc tính gel sản phẩm thì màng chitosan có hỗ trợ STPP cho thấy có tiềm năng hơn trong quá trình bảo quản lạnh đông.

\section{KẾT LUẬN}

Các kết quả nghiên cứu đã cho phép kết luận về vai trò tích cực của việc bao màng chitosan với nồng độ $1,5 \%$ giúp sản phẩm đảm bảo mật số vi sinh hiếu khí tổng số không vượt qua giới hạn cho phép của Bộ Y tể $\left(10^{5} \mathrm{CFU} / \mathrm{g}\right)$. Bao màng chitosan nồng độ $1,5 \%$ kết hợp STPP nồng độ $0,2 \%$ giúp chả cá lóc chiên có thể duy trì được chất lượng, đặc biệt an toàn vi sinh được đảm bảo tốt nhất ở điều kiện nhiệt độ mát $\left(4 \pm 2^{\circ} \mathrm{C}\right)$ đến 8 tuần và đến 12 tuần khi trữ đông $\left(-20 \pm 2^{\circ} \mathrm{C}\right)$.

\section{TÀI LIỆU THAM KHẢO}

Chamanara, V., Shabanpour, B., Khomeiri, M., \& Gorgin, S. (2013). Shelf-life extension of fish samples by using enriched chitosan coating with thyme essential oil. Journal of Aquatic Food Product Technology, 22(1), 3-10. https://www.researchgate.net/deref/http $\% 3 \mathrm{~A} \% 2 \mathrm{~F}$ $\% 2$ Ftandfonline.com\%2Floi\%2Fwafp20

Connell, J. J. (1990). Methods of assessing and selecting for quality. Control of fish quality, 2, 122-150.

Darmadji, P., \& Izumimoto, M. (1994). Effect of chitosan in meat preservation. Meat Science, 38(2), 243-254. https://doi.org/10.1016/03091740(94)90114-7

De Moura, M. R., Aouada, F. A., Avena-Bustillos, R. J., McHugh, T. H., Krochta, J. M., \& Mattoso, L. H. C. (2009). Improved barrier and mechanical properties of novel hydroxypropyl methylcellulose edible films with chitosan/tripolyphosphate nanoparticles. Journal of Food Engineering, 92(4), 448-453. http://dx.doi.org/10.1016/j.jfoodeng.2008.12.015

Devlieghere, F., Vermeulen, A., \& Debevere, J. (2004). Chitosan: Antimicrobial activity, interactions with food components and applicability as a coating on fruit and vegetables. Food Microbiology, 21(6), 703-714. https://doi.org/10.1016/j.fm.2004.02.008

Du, W. L, Niu, S. S., Xu, Y. L, Xu, Z. R., \& Fan, C. L. (2009). Antibacterial activity of chitosan tripolyphosphate nanoparticles loaded with various metal ions. Carbohydrate Polymers, 75(3), 385-389. https://doi.org/10.1016/j.carbpol.2008.07.039

Duan, J., Cherian, G., \& Zhao, Y. (2010). Quality enhancement in fresh and frozen lingcod (Ophiodon elongates) fillets by employment of fish oil incorporated chitosan coatings. Food Chemistry, 119(2), 52-532. http://dx.doi.org/10.1016/j.foodchem.2009.06.055

Entsar, S. A., Osheba, A. S., \& Sorour, M. A. (2012). Effect of chitosan and chitosan- nanoparticles as active coating on microbiological characteristics of fish fingers. International Journal of Applied Science and Technology, 2(1), 158-196.

Fan, W., Sun, J., Chen, Y., Qiu, J., Zhang Y., \& Chi, Y. (2009). Effects of chitosan coating on quality and shelf life of silver carp during frozen storage. Food Chemistry, 115(1), 66-70. https://doi.org/10.1016/j.foodchem.2008.11.060 
Honikel, K. O., \& Hamm, R. (1994). Measurement of water-holding capacity and juiciness. In: Advances in Meat Research. Vol. 9. Quality Attributes and Their Measurement in Meat, Poultry and Fish Products (ed. A.M. Pearson and T.R. Dutson). Blackie Academic and Professional. London, UK. 125-161.

Jeon, Y. J., Kamil, J. Y., \& Shahidi, F. (2002). Chitosan as an edible invisible film for quality preservation of herring and Atlantic cod. Journal of Agricultural and Food Chemistry, 50(18), 5167-5178. http://dx.doi.org/10.1021/jf0116931

Lê Xuân Sinh \& Đỗ Minh Chung. (2009). Khảo sát các mô hình nuôi cá lóc (Channa micropeltes và Channa striatus) ở đồng bằng sông Cửu Long. Kỷ yếu hội nghị khoa học thủy sản toàn quốc. Đại học Nông Lâm Tp HCM, 436-447.

Manat, C., Soottawat, B., Wonnop, V., \& Cameron, F., (2005). Changes of pigments and colour in sardine (Sardinella gibbosa) and mackerel (Rastrelliger kanagurta) muscle during iced storage. Food Chemistry, 93(4), 607-617. https://doi.org/10.1016/j.foodchem.2004.10.035

Morachis-Valdez, A. G., Gómez-Oliván, L. M., García-Argueta, I., Hernández-Navarro, M. D., Díaz-Bandera, D., \& Dublán-García, O. (2017). Effect of Chitosan Edible Coating on the Biochemical and Physical Characteristics of Carp Fillet (Cyprinus carpio) Stored at $-18^{\circ} \mathrm{C}$. International Journal of Food Science, 2,1-10. https://doi.org/10.1155/20172812483

Nguyen, V. M., Tran, T. T., \& Vo, H. N. (2019). The influence of additives on frozen snakehead fish surimi and the application of transglutaminase to fish cakes. Acta Scientiarum Polonorum Technologia Alimentaria, 18(2), 1-9. http://dx.doi.org/10.17306/J.AFS.2019.0636

Nguyễn Văn Mười. (2007). Công nghệ chế biến lạnh thực phẩm. Nhà xuất bản Giáo dục. 304 trang.
Nguyễn Văn Mười \& Trần Thanh Trúc. (2014). Giáo trình xử lý sau thu hoạch và chế biến sản phẩm động vật. Nhà xuất bản Đại học Cần Thơ.

Osheba, A. S., Sorour, M. A., \& Entsar, S.A. (2013). Effect of chitosan nanoparticles as active coating on chemical quality and oil uptake of fish fingers. Journal of Agriculture and Environmental Sciences (JAES), 2(1), 01-14.

Sathivel, S. (2005). Chitosan and protein coatings affect yield, moisture loss, lipid oxidation of pink salmon (Oncorhynchus gorbushcha) fillets during frozen storage. Journal of Food Science, 70(8), 755-459. https://doi.org/10.1111/j.13652621.2005.tb11514.x

Shahidi, F., Arachchi, J. K. V., \& Jeon, Y. J. (1999). Food applications of chitin and chitosans. Trends in Food Science and Technology, 10(2), 37-51. https://doi.org/10.1016/S0924-2244(99)00017-5

Singh, R. K., \& Balange, A. K., 2005. Characteristics of pink perch (Nemipterus japonicus) surimi at frozen temperature. Journal of Food Processing and Preservation, 29(1), 7583. https://doi.org/10.1111/j.17454549.2005.00014.x

Trần Thanh Trúc, Võ Hoàng Ngân \& Nguyễn Văn Mười. (2016). Ảnh hưởng của muối và các phụ gia đến sự tạo gel và đặc tính cấu trúc của chả cá lóc đông lạnh. Tạp chi khoa học Truờng Đại học Cần Tho', Số chuyên đề: Nông nghiệp, 1, 122130. https://doi.org/10.22144/ctu.jsi.2016.030

Tri, W. A., \& Sri, S. (2007). The Effect of chitosan concentration and storage time on the quality of salted-dried anchovy (Stolephorus heterolobus). Journal of Coastal Development, 10(2), 63-71.

Vo, H. N., Tran, T. T., \& Nguyen, V. M. (2018). Optimization of salt - water suplementation combined with other additives to improve the quality of snakehead fish cake. Proceedings of the third International Conference on Sustainable Global Agriculture and Food (November 2018) (pp. 296-310). 